\title{
PERAN PROFITABILITAS DALAM MEMODERASI PENGARUH FREE CASH FLOW TERHADAP KEBIJAKAN DIVIDEN DI INDONESIA
}

\author{
Angga Dwi Putra'), Irdha Yusra ${ }^{2)}$ \\ Sekolah Tinggi Ilmu Ekonomi KBP \\ angga.dwiputra76@gmail.com \\ irdhayusra@akbpstie.ac.id
}

\begin{abstract}
Basically, every company requires capital in order to finance their operational activity and to expand their business so capital becomes one of the important elements in a company. When the capital which is owned by the company is large the operational activity that can be conducted is large as well. This research is meant to test the influence of free cash flow on dividend policy with profitability as a moderating variable. The population is all companies which are listed in Indonesia Stock Exchange in 2013-2017 periods. The sample collection technique has been carried out by using purposive sampling method and based on the predetermined criteria, 26 companies have been selected as samples. The data of the financial statement of the companies has been obtained from the official website of IDX. The analytical method used is regression analysis with moderating variables using the SPSS application. Preliminary tests were carried out namely testing the classical assumptions to assess whether in an ordinary least square linear regression model there is a problem of classical assumptions, and testing to see the effect of moderation in influencing the relationship between independent variables and the dependent variable. The results of this observation state that free cash flow has a negative effect on dividend policy, free cash flow has a positive effect on dividend policy with profitability as a moderating variable.
\end{abstract}

Keywords: Free Cash Flow, dividend policy, profitability

\section{PENDAHULUAN}

Perusahaan yang terdaftar di Bursa Efek Indonesia (BEI) semakin bertambah jumlahnya. Hal ini menunjukkan semakin banyak pula transaksi saham yang terjadi di Bursa Efek Indonesia (BEI). Investor pasti menginginkan adanya tingkat pengembalian yang lebih tinggi dibandingkan pengorbanan yang telah dikeluarkan untuk mendapatkan investasi tersebut. Oleh karena itu, dividen menjadi salah satu pertimbangan bagi investor untuk menanamkan modalnya di suatu perusahaan untuk mencari tingkat pengembalian investasi (return). Di lain pihak, perusahaan juga mengharapkan pertumbuhan untuk kelangsungan hidup perusahaan (Hutasoit, 2017). Dibagian ini menjelaskan bahwa dividen sangat penting untuk seorang stakeholder dan juga investor unntuk dapat bekerja sama dengan perusahaan (Jayati, 2014).

Menghitung profitabilitas operasi dengan mengikuti perhitungan dalam Ball et al. (2015) penjualan dikurangi harga pokok penjualan dikurangi biaya penjualan, umum, dan administrasi. Ukuran ini menangkap kinerja operasi perusahaan dan tidak terpengaruh oleh item yang tidak beroperasi, seperti leverage dan pajak. Untuk mengevaluasi kemampuan bagian tunai dari profitabilitas operasi untuk memprediksi kembali, kami menghapus komponen akrual termasuk dalam perhitungan profitabilitas operasi untuk menciptakan ukuran profitabilitas 
operasional berbasis kas. Komponen-komponen ini adalah perubahan dalam piutang, persediaan, biaya dibayar dimuka, pendapat ditangguhkan, hutang dagang, dan masih harus dibayar biaya. Ukuran ini berbeda dari ukuran arus kas yang umum digunakan biasa ukuran arus kas yang digunakan dalam literatur harga aset adalah laba sebelum pos luar biasa tetapi setelah bunga, depresiasi, pajak, dan dividen yang disukai ditambah depresiasi. Ukuran ini mencakup akrual "modal kerja" seperti perubahan hutang, akun piutang, dan persediaan. Ukuran umum lainnya adalah arus kas dari operasi yang dihitung sesuai dengan prinsip akuntansi yang umumnya diterima, yang berada dari operasi berbasis uang tunai profitabilitas karena bersih dari pajak dan bunga dan karenanya merupakan ukuran arus kas yang terukur (Ball, Gerakos, Linnainmaa, \& Nikolaev, 2016).

Didalam teori ini free cash flow ketika perusahaan memiliki kelebihan kas, maka yang dibutuhkan adalah mendanai proyek yang memiliki Net Present Value (NPV) positif. Tetapi lebih baik bagi manajer untuk mengembalikan kelebihan kas kepada pemegang saham dalam bentuk dividen guna memaksimumkan kekayaan pemegang saham. Hal tersebut menunjukkan bahwa dividen dapat mengurangi agency cost karena mengurangi free cash flow yang tersedia bagi manajer.

Permasalahan free cash flow terjadi apabila tingkat pertumbuhan perusahaan rendah maka NPV nya akan positif. Jadi, perusahaan yang mempunyai pertumbuhan yang rendah akan melakukan investasi pada proyek dengan NPV negatif, yang mungkin memberikan benefit bagi manajer, baik dalam bentuk uang ataupun imbalan lainnya, namun akan menurunkan kinerja perusahaan. Selanjutnya, sebagai upaya untuk menutupi penurunan kinerja ini manajer akan melakukan akrual diskresioner yang meningkatkan laba. jadi, yang dimaksud dengan free cash flow adalah kelebihan cash flow yang ada diperusahaan setelah mendanai semua proyek investasi yang memiliki NPV positif.

Dari penelitian bermaksud meneliti free cash flow yang tinggi maka akan meningkatkan suatu laba pada perusahaan dan juga meneliti apakah hubungan tersebut diperlemah dengan adanya monitoring yang efektif oleh auditor, kreditur, dan komisaris independent (Tresnaningsih, 2008).

Teori kebijakan dividen secara kuat berkaitan dengan penelitian Miller \& Modigliani (1961) yang menunjukkan bahwa kebijakan dividen terkait dengan asumsi para investor yang rasional, pasar modal yang sempurna dan nilai pasar dari suatu perusahaan. Dalam empat abad terakhir dividen telah menjadi metode pembayaran utama pada setiap perusahaan perusahaan yang berada pada tahap mapan (Fama \& French, 2001). David (2010) mengungkapkan dividen sebagai metode yang paling populer dan efisien untuk mendistribusikan uang tunai kepada investor atau pemegang saham.

Kebijakan dividen dipandang sebagai keputusan yang sangat urgen dalam perusahaan, karena kebijakan tersebut menyangkut pihak-pihak yang memiliki tingkat kepentingan yang berbeda. Kebijakan dividen berhubungan dengan kebijakan pendanaan perusahaan. Dividen yang dibayarkan ditentukan oleh laba ditahan. Dividen yang dibayarkan akan semakin besar, jika laba yang ditahan perusahaan besar. Horne \& Wachowicz (1997) menyatakan bahwa penentuan laba sebagai laba ditahan dan pembayaran dividen adalah aspek utama dalam kebijakan dividen (Yusra, Herman, 2018).

Didalam penjelasan ini menyatakan kalau free cash flow tidak berpengaruh terhadap kebijakan deviden Hal ini karena investor menganggap bahwa aliran kas 
bebas yang dimiliki perusahaan digunakan sebagai investasi perusahaan dibandingkan dengan dibayarkan dividen kepada pemegang saham.

Hasil ini sesuai dengan penelitian yang dilakukan (Raissa, 2015) free cash flow tidak berpengaruh terhadap DPR. Artinya, besar kecilnya free cash flow yang dimiliki perusahaan tidak mempengaruhi besar kecilnya DPR yang dibayarkan pada pemegang saham. Hal ini mungkin saja terjadi apabila perusahaan menerapkan pembayaran dividen yang tetap, sehingga walaupun free cash flow yang dimiliki perusahaan besar, jumlah dividen yang dibagikan perusahaan nilainya tetap.

Semakin besar nominal cash flow per share suatu perusahaan maka tingkat dividend payments juga semakin besar. Hal ini dapat terjadi karena perusahaan yang memiliki angka cash flow per share lebih besar cenderung menunjukkan bahwa perusahaan tersebut memiliki ukuran perusahaan yang lebih besar, sehingga kemungkinan untuk pembayaran dividen akan semakin besar. Adapun Penelitian dilakukan (Efni, 2013), Lucyanda dan Lilyana (2012), mengatakan bahwa free cash flow berpengaruh positif terhadap kebijakan dividen. Semakin besar free cash flow maka semakin besar kebijakan dividen, karena semakin besar free cash flow yang dimiliki perusahaan maka manajemen akan mendapat tekanan yang besar dari para pemegang saham untuk membagikan dividen. Sedangkan penelitian (Lopolusi, 2013), menyatakan bahwa Free Cash Flow tidak berpengaruh terhadap kebijakan dividen. Hal ini mungkin saja terjadi apabila perusahaan menerapkan pembayaran dividen yang tetap, sehingga walaupun free cash flow yang dimiliki perusahaan besar, jumlah dividen yang dibagikan perusahaan nilainya tetap. Dari uraian di atas, dibangun hipotesis pertama sebagai berikut:

\section{$\mathrm{H}_{1}$ : Free Cash Flow berpengaruh negatif dan signifikan terhadap Kebijakan Dividen.}

ROA (return on asset) adalah rasio yang digunakan untuk mengukur kemampuan perusahaan memperoleh laba yang tersedia bagi pemegang saham perusahaan yang akan menjadi dasar pembagian dividen perusahaan. Rasio profitabilitas (ROA) dapat memberikan gambaran kepada perusahaan untuk mengetahui besarnya laba bersih yang dihasilkan oleh perusahaan dari aktiva yang dipergunakan. Minat investor berinvestasi tidak terlepas dari tujuan investor dalam memaksimalkan return, tanpa melupakan resiko yang harus dihadapi. Salah satu return yang dapat diperoleh investor adalah dividen, dividen merupakan hak pemegang saham terhadap laba yang dihasilkan oleh perusahaan. Seorang investor perlu melihat profitabilitas sebuah perusahaan sebelum memutuskan untuk melakukan investasi supaya dapat mengetahui seberapa banyak pendapatan yang akan dihasilkan dari investasi (Nur Diana 1 Hasudungan Hutasoit2, 2006).

Perusahaan dengan laba yang tinggi mampu membayar dividen yang lebih tinggi (Brigham, 2001:24).Para manajer tidak hanya mendapatkan dividen yang dibagikan, tetapi juga power yang lebih besar dalam menentukan kebijakan perusahaan. Perusahaan yang memperoleh keuntungan besar cenderung akan membayarkan deviden lebih besar. Hal tersebut semakin besar keuntungan yang diperoleh mencerminkan profitabilitas yang tinggi sehingga semakin besar pula kemampuan perusahaan untuk membayar deviden. 
Profitabilitas adalah kemampuan perusahaan dalam menghasilkan laba selama periode tertentu yang dapat dihitung berdasarkan perbandingan penjualan dengan total aktiva permodal sendiri. Hal ini dapat dijelaskan bahwa untuk mengetahui profitabilitas suatu perusahaan sangat penting bagi investor maupun kreditur. Sementara itu, pihak lain ingin mengetahui kemampuan perusahaan dalam menghasilkan kas. Informasi profitabilitas dapat mengindikasikan kemampuan perusahaan dalam menghasilkan kas di masa yang akan datang. Informasi arus kas dapat diperoleh dari laporan arus kas. Salah satu teknik dalam menilai profitabilitas perusahaan adalah dengan menggunakan Return on Total Asset (ROA). Free cash flow menunjukkan kemampuan perusahaan untuk menghasilkan kas dari kegiatan usahanya setelah melakukan investasi dan pembayaran hutang serta dividen. Dapat disimpulkan semakin besar laba yang dihasilkan dan free cah flow menujukkan hasil yang baik maka akan semakin besar dividen yang akan diterima pemegang saham.(Diana, Hutasoit, 2006).

Sedangkan free cash flow berpengaruh terhadap profitabilitas karena tingkat keuntungan perusahaan ditentukan dari harga saham yang dimiliki investor yang harus dilakukan perusahaan untuk meningkatkan saham yang ada diperusahaan (Mardasari, 2014). Dari uraian di atas, dibangun hipotesis kedua sebagai berikut:

\section{$\mathrm{H}_{2}$ : Profitabilitas memoderasi secara signifikan pengaruh free cash flow terhadap kebijakan dividen.}

\section{METODE PENELITIAN \\ Data dan Sampel}

Penelitian ini dilakukan pada perusahaan yang terdaftar di Bursa Efek Indonesia. Alasan pemilihan obyek ini adalah dalam pemilihan sampel tidak terdapat kendala kekurangan data, dan titik informasi yang pasti mengenai industri yang telah go publik.

Sumber data utama dalam penelitian ini menggunakan Annual Report dan Summary. Jenis data yang didapatkan dari Annual Report dan Summary berupa data kuantitatif. Data kuantitatif yang digunakan seperti laporan laba rugi, laporan ekuitas, laporan neraca. Teknik pengumpulan data yang digunakan dalah dokumentasi.

Populasi pada pengamatan ini yaitu Perusahaan yang terdaftar pada Bursa Efek Indonesia di akhir periode observasi, yaitu 2017 sebanyak 539 Perusahaan. Metode pemilahan sampel pada pengamatan ini dilakukan dengan metode purposive sampling yaitu metode penarikan sampel dengan penilaian yang berdasarkan pada kategori sesuai dengan objek maupun subjek yang untuk diamati. Kriteria untuk pengambilan sampel pada pengamatan ini yaitu :

1. Perusahaan terdaftar di BEI akhir periode Observasi, yaitu Tahun 2017.

2. Perusahaan tidak terdaftar di BEI berturut-turut selama periode Observasi (2013-2017).

3. Perusahaan terdaftar di BEI yang Tidak menerbitkan Laporan Keuangan selama periode observasi (2013-2017).

4. Perusahaan yang tidak memiliki data keuangan sesuai dengan variabel yang akan diuji yaitu Free Cash Flow, Kebijakan Dividen, Profitabilitas.

5. Perusahaan yang memiliki data outlier. 
berikut:

Berdasarkan kriteria-kriteria tersebut, maka diperoleh sampel pada Tabel

\section{Tabel 1}

Tabulasi Pengambilan Sampel Menggunakan Purposive Sampling

\begin{tabular}{clc}
\hline No & \multicolumn{1}{c}{ Kiteria } & Jumlah \\
\hline 1 & $\begin{array}{l}\text { Perusahaan yang terdaftar di BEI pada akhir periode observasi, } \\
\text { yaitu 2017 }\end{array}$ & 539 \\
2 & $\begin{array}{l}\text { Perusahaan yang tidak terdaftar berturut-turut selama periode } \\
\text { observasi (2013-2017) }\end{array}$ & $(142)$ \\
3 & $\begin{array}{l}\text { Perusahaan terdaftar yang tidak menerbitkan laporan keuangan } \\
\text { selama periode observasi (2013-2017). }\end{array}$ & $\begin{array}{l}\text { (113) } \\
\text { Perusahaan yang tidak memiliki data keuangan yang seseuai } \\
\text { dengan variabel-variabel yang akan di uji yaitu, FCF,DPR, dan }\end{array}$ \\
\hline $\begin{array}{l}\text { ROA } \\
5\end{array}$ & $\begin{array}{l}\text { Perusahaan yang memiliki data outlier } \\
\text { Sampel Akhir }\end{array}$ & (150) \\
\hline & Jumlah Observasi & 130 \\
\hline
\end{tabular}

sumber : Diolah Peneliti, 2018

\section{Definisi Operasional Variabel}

Dalam penelitian ini terdiri dari dua macam variabel yaitu variabel independent dan dependent. Variabel independent yaitu Likuiditas $\left(\mathrm{X}_{1}\right)$, Ukuran Perusahaan $\left(\mathrm{X}_{2}\right)$, Volatilitas Laba $\left(\mathrm{X}_{3}\right)$. Variabel dependent yaitu Leverage $(\mathrm{Y})$. Selanjutnya dapat diuraikan definisi operasionalnya dari pengamatan ini sebagai berikut:

Tabel 2

Definisi Operasional Variabel

\begin{tabular}{cclcc}
\hline No & $\begin{array}{c}\text { Vari } \\
\text { abel }\end{array}$ & \multicolumn{1}{c}{ Definisi } & Pengukuran & Sumber \\
\hline 1 & Free & adanya biaya & FCF= & $\begin{array}{c}\text { Mardasar } \\
\text { i, 2014 }\end{array}$ \\
& Cas & operasi yang & Aliran Kas Operasi-capital Expenditure: & \\
& diharapkan dan & Total Asset & \\
& Flo & investasi yang & & \\
& diperlukan untuk & & \\
& $(\mathrm{X})$ & mempertahankan & & \\
& & dan meningkatkan \\
& & & \\
\hline
\end{tabular}




\begin{tabular}{|c|c|c|c|c|}
\hline 2 & $\begin{array}{c}\text { Kebi } \\
\text { jaka } \\
\text { n } \\
\text { Devi } \\
\text { den } \\
(Y)\end{array}$ & $\begin{array}{l}\text { Mendefenisikan } \\
\text { keputusan } \\
\text { dividend payout } \\
\text { ratio adalah } \\
\text { mengenai } \\
\text { seberapa besar } \\
\text { laba yang akan } \\
\text { dibagikan kepada } \\
\text { pemegang saham } \\
\text { untuk dibayarkan } \\
\text { sebagai dividen, } \\
\text { sebagai ganti } \\
\text { investasi dapat } \\
\text { doipertahankan } \\
\text { dalam perusahaan }\end{array}$ & $\mathrm{DPR}=\frac{\text { Deviden Perlembar Saham }}{\text { Laba Perlembar Saham }}$ & $\begin{array}{l}\text { (Fahmi, } \\
\text { 2014) }\end{array}$ \\
\hline 3 & $\begin{array}{l}\text { Profi } \\
\text { tabil } \\
\text { itas } \\
(\mathrm{Z})\end{array}$ & $\begin{array}{l}\text { Ukuran rasio ini } \\
\text { untuk operasi } \\
\text { efisiensi bagi } \\
\text { perusahaan } \\
\text { berdasarkan laba } \\
\text { yang dihasilkan } \\
\text { perusahaan dari } \\
\text { total aset }\end{array}$ & $\begin{array}{c}\text { ROA } \\
=\frac{\text { Laba Bersih Setelah Pajak }}{\text { Total Asset }} X 100 \%\end{array}$ & $\begin{array}{l}\text { (Nu'aim } \\
\text { at, 2012) }\end{array}$ \\
\hline
\end{tabular}

\section{Teknik Analisis Data}

Dalam penelitian ini data yang digunakan yaitu data panel, yang merupakan gabungan antara data time series dan cross section. Data sampel sebanyak 26 perusahaan diambil dari data unit cross section dan data time series periode 20132017.

Analisis statistik deskriptif merupakan metode analisis yang digunakan dalam penelitian ini dan menggunakan Program SPSS untuk analisis regresi dengan variabel moderating. Persamaan regresi data panel yang digunakan dalam penelitian ini adalah:

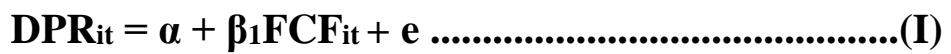

$$
\begin{aligned}
& \mathrm{DPR}_{\text {it }}=\alpha+\beta_{1} \mathrm{FCF}_{\text {it }}+\beta_{2} \mathrm{ROA}_{\mathrm{it}}+\boldsymbol{\beta}_{3} \mathrm{SNM}_{i t}+\mathrm{e} . . . . . . . . . .(\text { II })
\end{aligned}
$$

Dimana $\mathrm{DPR}_{\text {it }}$ merupakan Kebijakan Dividen Perusahaan pada waktu t, $\alpha$ merupakan konstanta (intercept), $\beta 1, \beta 2$ merupakan Koefisien Regresi, $\mathrm{FCF}_{\text {it }}$ merupakan Free Cash Flow Perusahaan pada waktu t, $\mathrm{ROA}_{\text {it }}$ merupakan Profitabilitas Perusahaan pada waktu t, $\mathbf{S N M}_{\mathrm{it}}$ merupakan Selisih Nilai Mutlak Perusahaan pada waktu t dan e merupakan Standar error.

Pendekatan yang dilakukan dalam analisis regresi dengan variabel moderating yaitu Uji Normalitas, dan Uji Heteroskedastisitas. Ada dua tahapan 
yang dilakukan untuk menentukan model yang terbaik digunakan antara model tersebut yaitu: Uji Normalitas, untuk menentukan normalnya suatu data. Uji Heteroskedastisitas, dilakukan untuk menentukan dalam model regresi terjadi ketidaksamaan varians dari residual satu pengamatan ke pengamatan lainnya. Model regresi yang baik harus menghasilkan estimasi linear tidak bias (Best Linear Unbiased Estimator).

\section{HASIL DAN PEMBAHASAN Uji Statistik Deskriptif Variabel}

Tabel 4

Hasil Uji Statistik Deskriptif

\begin{tabular}{lccccc}
\hline \multicolumn{1}{c}{ Variabel } & N & Minimum & Maximum & Mean & $\begin{array}{c}\text { Std. } \\
\text { Deviation }\end{array}$ \\
\hline Free Cash Flow (FCF) & 130 & -4.61 & 5.42 & -.9885 & 2.73100 \\
Kebijakan Deviden (DPR) & 130 & -4.99 & 3.51 & -.8014 & 1.19960 \\
Profitabilitas (ROA) & 130 & -.71 & 4.19 & 2.0096 & .94661 \\
\hline
\end{tabular}

Pada tabel 4 menunjukkan angka-angka deskriptif dari masing-masing variabel dengan jumlah observasi sebanyak 130 (seratus tiga puluh). Penjelasan dari analisis deskriptif adalah sebagai berikut :

Kebijakan Dividen merupakan variabel terikat dengan menggunakan DPR sebagai alat ukur. Nilai minimum sebesar -4.99 diperoleh oleh perusahaan Multi Bintang Indonesia Tbk tahun 2014 dan nilai maximum sebesar 3.51 yang dimiliki oleh perusahaan yang diperoleh Argha Karya Prima Industry Tbk tahun 2017. Nilai rata-rata (mean) adalah teknik penjelasan kelompok yang didasarkan atas nilai ratarata dari kelompok tersebut yang didapat dengan menjumlahkan data seluruh individu dalam kelompok. Nilai mean sebesar -0.80 menjelaskan bahwa nilai ratarata DPR dibawah 1. Standar deviasi adalah bentuk pengukuran yang digunakan untuk mengukur jumlah variasi atau sebaran sejumlah nilai data yang pada dasarnya menggambarkan besaran sebaran suatu kelompok data terhadap rata-ratanya atau dengan kata lain gambaran keheterogenan suatu suatu kelompok data, Standar deviasi DPR sebesar 1.20 yang menunjukkan penyebaran data yang lebih besar karena nilainya lebih tinggi dari nilai rata-rata (mean).

Alat ukur free cash flow menggunakan FCF. Nilai minimum FCF sebesar 4.61 menunjukkan bahwa biaya yang dikeluarkan tidak dapat didiskontokan keperusahaan yang diperoleh oleh Ekadharma International Tbk tahun 2014 dan nilai maximum FCF sebesar 5.42 menunjukan bahwa biaya yang dikeluarkan berlebih maka dapat didiskontokan keperusahaan yang diperoleh oleh Supreme Cable Manufacturing \& commerce Tbk tahun 2016. Nilai mean FCF sebesar -0.98 menunjukkan bahwa biaya yang dikeluarkan tidak dapat didiskontokan keperusahaan. Standar deviasi FCF sebesar 2.73 yang menunjukkan menunjukkan penyebaran data yang lebih besar karena nilainya lebih tinggi dari nilai rata-rata (mean).

Profitabilitas sebagai variabel moderating menggunakan ROA sebagai alat ukurnya. Nilai minimum ROA sebesar $-0.71 \%$ menunjukan bahwa profit yang diterima rendah tidak dapat dilakukannya investasi yang diperoleh oleh perusahaan 
Argha Karya Prima Industry Tbk tahun 2017. Nilai maximum ROA sebesar 4.19\% menunjukan bahwa profit yang terima tinggi perusahaan dapat melakukan investasi yang diperoleh oleh Multi Bintang Indonesia Tbk tahun 2013. Nilai sebesar 2.01\% menunjukan bahwa perusahaan mampu memperoleh laba bagi perusahaan. Standar deviasi dari ROA sebesar 0.95 yang menunjukkan penyebaran data lebih kecil karena nilainya lebih rendah dari nilai rata-rata (mean).

\section{Uji Asumsi Klasik}

\section{Uji Normalitas}

Dalam mendeteksi data terdistribusi secara normal atau tidak normalnya data, pada penelitian ini menggunakan uji One-Kolmogorov-Smirnov test. Dalam pengambilan keputusan dari uji normalitas ini adalah dengan melihat nilai Asymp.Sig (2-tailed). Jika nilai Asymp.Sig (2-tailed) $>\alpha=0.05$, maka data tersebut terdistribusi secara normal.

Tabel 5

Hasil Uji Normalitas

\begin{tabular}{ccc}
\hline & $\begin{array}{l}\text { Standardized } \\
\text { Residual }\end{array}$ & Keterangan \\
\hline Kolmogorov-Smirnov $Z$ & 1.195 & Data terdistribusi normal \\
Asymp. Sig. (2-tailed) & 0.115 & \\
\hline
\end{tabular}

Sumber: data diolah, SPSS

Pada tabel diatas dengan uji One-Sample Kolmogorov-Smirnov Test hasil dari uji tersebut menunjukan asymp. sig standardized residual adalah 0.115 . Hal ini dapat disimpulkan bahwa nilai signifikannya lebih besar dari alpha 0.05 dengan demikian menunjukan data terdistribusi secara normal.

\section{Uji Heteroskedastisitas}

Pada uji heteroskedastisitas untuk mendeteksi ada atau tidaknya heteroskedastisitas dapat dilakukan dengan uji Glejser. Dalam uji ini apabila signifikasinya diatas tingkat kepercayaan 5\% (0,05). Jadi disimpulkan ,model regresi tidak mengandung adanya heteroskedastisitas.

Tabel 6

Hasil Uji Heteroskedastisitas

\begin{tabular}{cccc}
\hline Variabel & Alpha & Asymp.Sig & Keterangan \\
\hline Free Cash Flow $($ FCF) & 0,05 & 0.894 & $\begin{array}{c}\text { Tidak terjadi } \\
\text { Heteroskedastisitas }\end{array}$ \\
\hline
\end{tabular}

Sumber: data diolah, SPSS

Berdasarkan hasil uji heteroskedastisitas dapat dilihat pada tabel 6 diatas menunjukan bahwa nilai Asymp. Sig pada variabel bebas (independen) menunjukan lebih besar dari alpha 0,05 sehingga dapat disimpulkan bahwa semua variabel independen pada penilitian ini tidak terjadi heteroskedastisitas. 


\section{Analisis Regresi Linear dengan Variabel Moderating}

Analisis regresi linear dengan variabel moderating ini, digunakan untuk melihat hubungan antara sebuah variabel dependen (tidak bebas) dengan variabel independen (bebas) pada model I (satu). Sedangkan pada model II (dua), analisis linear dengan variabel moderating digunakan dalam melihat pengaruh moderasi dalam mempengaruhi hubungan antara variabel independen terhadap variabel dependen.

\section{Analisis Regresi Model I}

Tabel 7

Tabel Hasil Estimasi Model Regresi Dengan Variabel Moderating

\begin{tabular}{cc} 
Keterangan & Koefisien \\
\hline Konstanta & -0.745 \\
Free Cash Flow & 0.057 \\
(FCF) &
\end{tabular}

Sumber : data diolah, SPSS

Berdasarkan hasil analisis regresi linear model I diperoleh persamaan sebagai berikut:

$\mathrm{DPR}=-0.74+0.14 \mathrm{FCF}+\mathrm{e}$

Persamaan regresi berganda diatas dapat diartikan bahwa:

Nilai Konstanta yaitu -0.74 dengan parameter negatif yang mana dapat disimpulkan bahwa nilai Kebijakan Dividen adalah sebesar -0.74 dengan asumsi variabel lain bernilai nol. Nilai Koefisien regresi free cash flow yaitu 0.14 dengan parameter positif yang mana dapat disimpulkan bahwa setiap peningkatan satusatuan free cash flow maka akan mengakibatkan kenaikan kebijakan dividen sebesar 0.14 .

\section{Analisis Regersi Linear Model II}

Analisis regresi model ke 2 (dua) adalah analisis regresi yang digunakan untuk menganalisa pengaruh moderasi. Dalam penelitian ini analisis regresi model ke 2 digunakan untuk menganalisa profitabilitas memoderasi pengaruh free cash flow dengan kebijakan dividen. Adapun teknik yang digunakan dalam analisis regresi bertingkat yaitu teknik Moderating Regression Analysis (MRA).

Tabel 8

Tabel Hasil Estimasi Model Regresi Dengan Variabel Moderating

\begin{tabular}{cc}
\hline Keterangan & Koefisien \\
\hline Konstanta & -1.220 \\
Free Cash Flow (FCF) & 0.004 \\
Profitabilitas (ROA) & -0.010 \\
Selisih Nilai Mutlak (SNM) & 0.361 \\
\hline
\end{tabular}

Sumber : data diolah, SPSS

Berdasarkan hasil analisis data model II diperoleh persamaan sebagai berikut :

$\mathrm{DPR}=-1.220+0.004 \mathrm{FCF}-0.010 \mathrm{ROA}+0.361 \mathrm{SNM}$

Nilai Konstanta yaitu -1.220 dengan parameter negatif yang mana dapat disimpulkan bahwa nilai kebijakan dividen adalah sebesar -1.220 dengan asumsi variabel lain bernilai nol. Nilai Koefisien regresi free cash flow yaitu 0.004 dengan 
parameter positif yang mana dapat disimpulkan bahwa setiap peningkatan satusatuan free cash flow maka akan mengakibatkan kenaikan kebijakan dividen sebesar 0.004 . Koefisien return on asset sebesar -0.010 artinya setiap peningkatan variabel return on asset sebanyak 1 satuan akan menurunkan variabel kebijakan dividen sebesar -0.010. Koefisien Selisih Nilai Mutlak (SNM) sebesar 0.361 artinya setiap peningkatan variabel selisih nilai mutlak sebanyak 1 satuan akan meningkatkan variabel kebijakan dividen sebesar 0.361 .

\section{Uji Hipotesis (t-test)}

Uji T (Uji individu) merupakan uji koefisien regresi masing-masing variabel bebas terhadap variabel terikat untuk mengetahui seberapa besar pengaruh variabel bebas terhadap variabel dependen. Hasil estimasi model regresi untuk melihat penerimaan atau penolakan hipotesis adalah sebagi berikut :

Tabel 9

Hasil Uji Statistik t

Analisi Regresi Linear Tahap I dan Tahap II

\begin{tabular}{lccccc}
\hline \multirow{2}{*}{ Variabel } & \multirow{2}{*}{ t-tabel } & \multicolumn{2}{c}{ Tahap I } & \multicolumn{2}{c}{ Tahap II } \\
\cline { 3 - 6 } & & T & Sig. & t & Sig \\
\hline Free Cash Flow (FCF) & 2.06 & 1.48 & 0.14 & 0.08 & 0.93 \\
Profitabilitas (PROF) & 2.06 & & & -0.09 & 0.92 \\
Selisih Nilai Mutlak & 2.06 & & & 2.14 & 0.03 \\
(SNM) & & & & & \\
\hline
\end{tabular}

Sumber : data diolah, SPSS

Adapun hasil dari pengujian statistik t (uji t) pada penilitian ini adalah sebagai berikut :

Uji t pada variabel free cash flow $\left(\mathrm{X}_{1}\right)$ diperoleh $\mathrm{t}$ hitung lebih kecil dari $\mathrm{t}$ tabel $(1.48<2.06)$ dengan nilai signifikan lebih besar dari alpha $(0.14>0.05)$ Hal ini menunjukan bahwa variabel free cash flow $\left(\mathrm{X}_{1}\right)$ tidak berpengaruh signifikan terhadap kebijakan deviden (Y). Hasil uji $\mathrm{t}$ ini berarti menolak hipotesis $1\left(\mathrm{H}_{1}\right.$ ditolak).

Moderasi dilakukan dengan menggunakan SNM antara variabel free cash flow dengan profitabilitas. Hasil pengujian menunjukkan nilai thitung lebih besar dari $t_{\text {tabel }}(2.14>2.06)$ atau nilai signifikan lebih kecil dari alpha $(0.03<0.05)$. Hal ini menunjukan bahwa variabel profitabilitas ( $Z$ ) memoderasi secara signifikan pengaruh free cash flow (X1) dengan variabel kebijakan dividen (Y). Dengan demikian disimpulkan bahwa $\mathrm{H}_{2}$ diterima. Signifikannya variabel moderasi menunjukkan bahwa profitabilitas bisa memperkuat pengaruh free cash flow terhadap kebijakan dividen.

\section{PEMBAHASAN}

\section{Pengaruh Free Cash Flow Terhadap Kebijakan Dividen}

Berdasarkan hipotesis pertama $\left(\mathrm{H}_{1}\right)$ yang dikemukakan dalam penelitian ini yaitu, Bahwa diduga free cash flow berpengaruh positif signifikan terhadap kebijkan dividen. Sedangkan berdasarkan uji nilai t hitung untuk variabel Free Cash Flow membuktikan bahwa $\mathrm{H}_{1}$ ditolak. Artinya tidak ada pengaruh yang signifikan antara free cash flow terhadap kebijakan dividen. 
Besar kecilnya aliran kas bebas tidak mempengaruhi deviden payout ratio yang dibayarkan kepada seorang pemegang saham suatu perusahaan. Karena aliran kas bebas yang dikeluarkan perusahaan tidak ada hubungan dengan pemegang saham (Mardasari, 2014).

Hasil pengujian menggunakan analisis jalur dimana variabel free cash flow tidak berpengaruh dengan kebijakan dividen. Sehingga rendahnya FCF tidak memiliki pengaruh terhadap dividen yang akan dibagikan kepada pemegang saham. Hal ini karena investor menganggap bahwa aliran kas bebas yang dimiliki perusahaan digunakan sebagai investasi perusahaan dibandingkan dengan dibayarakan dividen kepada pemegang saham. Sehingga aliran kas bebas tidak berpengaruh terhadap kebijakan dividen.

\section{Pengaruh Free Cash Flow terhadap Kebijakan Deviden dengan Profitabilitas sebagai Pemoderasi}

Hasil pengujian hipotesis yang telah dilakukan pada hipotesis 2 menunjukan bahwa secara positif variabel Profitabilitas memoderasi pengaruh free cash flow terhadap variabel kebijakan dividen. Positifnya nilai koefisien variabel profitabilitas (ROA) yang dilihat dari nilai selisih mutlak menjelaskan bahwa profitabilitas dapat memperkuat hubungan pengaruh antar free cash flow terhadap kebijakan dividen.

Profitabilitas mendapatkan hasil bersih dari serangkaian kebijakan dan keputusan (Brigham \& Huston, 2011). Kebijakan manajemen mempengaruhi pembagian dividen yang tentunya mempertimbangkan berbagai hal, diantaranya adalah tujuan laba apakah akan digunakan untuk investasi lebih lanjut atau dibagikan menjadi dividen dan dipengaruhi oleh ketersediaan free cash flow pada perusahaan. Maka dari itu, pengawasan lebih dibutuhkan terhadap perusahaan tingkat free cash flow yang tinggi dengan profitabilitas yang rendah (Nur Diana 1 Hasudungan Hutasoit2, 2006).

Hasil penelitian ini sesuai dengan hasil penelitian yang telah dilakukan oleh (Nur Diana 1 Hasudungan Hutasoit2, 2006) yang meneliti tentang pengaruh free cash flow dan kepemilikan institusional terhadap kebijakan dividen dengan profitabilitas sebagai variabel moderating. Hasil penelitiannya menunjukkan bahwa Profitabilitas mempengaruhi hubungan antara free cash flow dengan variabel kebijakan dividen.

\section{SIMPULAN}

Hasil dari penelitian pengaruh Free Cash Flow (FCF) terhadap kebijakan dividen (DPR) dengan Profitabilitas (ROA) sebagai Variabel Moderating Return Saham dapat disimpulkan sebagai berikut :

1. Free Cash Flow tidak berpengaruh terhadap kebijakan dividen pada perusahaan yang terdaftar di Bursa Efek Indonesia periode 2013-2017. Artinya, Besar kecilnya aliran kas bebas tidak mempengaruhi deviden payout ratio yang dibayarkan kepada seorang pemegang saham suatu perusahaan.

2. Profitabilitas secara signifikan memoderasi pengaruh free cash flow terhadap kebijakan dividen pada perusahaan yang terdaftar di Bursa Efek 
Indonesia periode 2013-2017. Artinya, Profitabilitas akan mampu memperkuat pengaruh free cash flow terhadap kebijakan dividen.

\section{UCAPAN TERIMA KASIH}

Selesainya penulisan ini, karena penulis banyak menerimamasukan dan dorongan baik motivasi secara moral atau spiritual. Oleh karena itu penulis ingin mengucapkan terimakasih kepada:

1. Bapak Febryandhie Ananda, SE, Msi. selaku ketua STIE”KBP” Padang

2. Ibu Febsri Susanti, SEI, MM. selaku ketua Program Studi Manajemen

3. Bapak Irdha Yusra SE, MSc. sebagai dosen pembimbing dalam pembuatan skripsi ini dan penulis banyak berterima kasih atas kesabaran, kepedulian dan kesempatan yang sudah diberikan, penulis berharap kebaikan bapak bisa dibalas oleh Tuhan Yang Maha Esa

4. Seluruh bagian yang sudah banyak menolong penulis yang tidak dapat penulis sampaikan satu persatu.

\section{DAFTAR PUSTAKA}

Arimbawa, I. K. T., \& Badera, I. D. N. (2018). Pengaruh Tingkat Perputaran Aktiva Lancar , Perputaran Modal Kerja , Likuiditas , Ukuran Perusahaan , Pertumbuhan Koperasi Terhadap Profitabilitas Fakultas Ekonomi Dan Bisnis Universitas Udayana ( Unud ), Bali , Indonesia Fakultas Ekonomi Dan Bisnis Unive, 22, 158-186.

Ball, R., Gerakos, J., Linnainmaa, J. T., \& Nikolaev, V. (2016). Accruals, Cash flows, And Operatin. Journal of Financial Economics. Https://Doi.Org/10.1016/J.Jfineco.2016.03.002

Said Mukhled Ahmed AL Nu'aimat, D. F. N. D. (2012). The Relationship Between The ROA, ROE And ROI Ratios With Jordanian Insurance Public Companies Market Share Prices, 2(11), 115-120.

Efni, Y. (2013). Analisis Kebijakan Pendanaan, Kepemilikan Manajerial Dan Aliran Kas Bebas Terhadap Kebijakan Dividen Pada Perusahaan Non Manufaktur Yang Terdaftar Di Bursa Efek Indonesia ( BEI ). Jurusan Manajemen Fakultas Ekonomi Universitas Riau, 19(1). Https://Doi.Org/10.3389/Fpsyg.2012.00169

Elen Puspitasari, A. N. S. (2012). Pengaruh Karakteristik Perusahaan Terhadap Lamanya Waktu Penyelesaian Audit ( Audit Delay ) Pada Perusahaan Manufaktur Yang Terdaftar Di Bursa Efek Elen Puspitasari Anggraeni Nurmala Sari Universitas Stikubank Semarang, 9(1), 31-42.

Fahmi, I. (2014). Pengantar Manajemen Keuangan. (M. A. Djalil, Ed.). ALFABETA.

Gitosudarmo, I., \& Basri. (2002). Manajamen Keuangan (4th Ed.). BPFEYOGYAKARTA.

Husnan, S., \& Pudjiastuti, E. (2012). Dasar-Dasar Manajemen Keuangan (6th Ed.). UPP STIM YKPN.

Hutasoit, H. (2017). Pengaruh Free Cash Flow Dan Kepemilikan Institusional Terhadap Kebijakan Deviden Sebagai Variabel Moderating, 2(2), 77-89.

Jayati, L. (2014). Analisis Pengaruh Cash Flow Terhadap Kebijakan Dividen Perusahaan Dengan Size Perusahaan Dan Life , 3(2011), 1-9.

Kasmir. (2016). Analissi Laporan Keuangan. PT Rajagrafindo Persada. 
Keown, A. J., Martin, J. D., Petty, J. W., \& Jr, D. F. S. (2008). Manajemen Keuangan: Prinsip Dan Penerapan. (M. P. Widodo, Ed.) (10th Ed.).

Lopolusi. (2013). Analisis Faktor-Faktor Yang Mempengaruhi Kebijakan Dividen Sektor Manufaktur Yang Terdaftar Di PT Bursa Efek Indonesia Periode 20072011. Calyptra, 2(1), 1-17. Https://Doi.Org/10.1002/Cbic.200800077

Mardasari, R. B. (2014). Pengaruh Insider Ownership, Kebijakan Hutang Dan Free Cash Flow Terhadap Nilai Peruahaan Melalui Kebijakan Deviden, 2.

Mardiyati, U. (2012). Pengaruh Kebijakan Dividen, Kebijakan Hutang Dan Profitabilitas Terhadap Nilai Perusahaan Manufaktur Yang Terdaftar Di Bursa Efek Indonesia, 3(1), 1-17.

Nur Diana 1 Hasudungan Hutasoit2. (2006). Pengaruh Free Cash Flow Dan Kepemilikan Institusional Terhadap Kebijakan Dividen Dengan Profitabilitas Sebagai Variabel Moderating, 2(2), 1-84. Https://Doi.Org/10.1002/9781118266847.Ch3

Raissa, F. (2015). Faktor-Faktor Yang Mempengaruhi Kebijakan Deviden Pada Perusahaan Yang Tercatat Di Pt Bursa Efek Indonesia.

Sugiyono. (2017a). Metode Penelitian Bisnis. (S. Sofia Yustiyani, Ed.). Bandung.

Sugiyono, P. D. (2017b). Metode Penelitian Bisnis. ( Suryandari Sofia Yustiyani, Ed.) (Edisi 3). Bandung.

Tresnaningsih, E. (2008). Menajemen Laba Pada Perusahaan Dengan Permasalahan Free Cash Flow Dan Peran Moderasi Dari Monitoring Eksternal, 5(2), 30-49.

Weston, J. F., \& Brigham, E. F. (1985). Managerial Finance. (G. Hutauruk, Ed.) (7th Ed.). Erlangga.

Yusra, Herman, B. (2018). Model Kebijakan Dividen Berdasarkan Siklus Hidup Perusahaan : Studi Empiris Di Indonesia. Jurnal Benefita, 3(2), 263-276.

Yusra, I., Hadya, R., \& Egawati, N. (2017). Analisis Efektivitas Pengendalian Biaya, Perputaran Modal Kerja, Dan Rentabilitas Ekonomi Menggunakan Regresi Data Panel, 01(03), 153-166. 